\title{
Ex-situ cultivation of Isoetes cangae and Isoetes serracarajensis (Isoetaceae) two endemic species from Brazilian Amazon
}

\author{
Authors: Daniel Basílio Zandonadi ${ }^{*}$, Rodrigo Lemes Martins ${ }^{1}$, Luis Alfredo \\ dos Santos Prado ${ }^{1}$, Heitor Monteiro Duarte ${ }^{1}$, Mirella Pupo Santos ${ }^{1}$, Emiliano \\ Calderon ${ }^{1}$, Ana Carolina Almeida Fernandes ${ }^{1}$, Quézia Souza Santos ${ }^{1}$, Filipe \\ Junior Gonçalves Nunes ${ }^{1}$, Luis Carlos Felisberto Ribeiro ${ }^{1}$, Taís Nogueira \\ Fernandes ${ }^{2}$, Alexandre Castilho ${ }^{3}$, and Francisco de Assis Esteves ${ }^{1}$
}

${ }^{1}$ Instituto de Biodiversidade e Sustentabilidade (NUPEM) Universidade Federal do Rio de Janeiro (UFRJ), Macaé, Rio de Janeiro, Brazil.

${ }^{2}$ Environmental Studies Office, Vale, Belo Horizonte, MG, Brazil.

${ }^{3}$ Gerência de Meio Ambiente Corredor Norte, Vale, Belo Horizonte, MG, Brazil.

${ }^{*}$ Author for correspondence: Daniel B. Zandonadi: Instituto de Biodiversidade e Sustentabilidade (NUPEM/UFRJ) Universidade Federal do Rio de Janeiro, Macaé, Rio de Janeiro, Brazil. Telephone: +55 22 999232617; E-mail: dz@ufrj.br

\begin{abstract}
Isoetes L. is a genus of lycophytes widely distributed around the world that has a large number of endemic species. Here we document the first successful large scale ex-situ cultivation of the new endemic species from Brazilian Amazon quillworts Isoetes cangae and Isoetes serracarajensis.
\end{abstract} These isoetids are endemic of an iron mining site and grow on a superficial 
iron crust that occurs over ferriferous rocks. This study aimed to develop the cultivation methods of the threatened species $I$. cangae and monitoring its unique physiology. Plants from both species brought from Amazon lagoons were cultivated through a year in a low-cost system at a different site during different seasons. The survival rate of plants was higher as $98 \%$ and both species developed well under cultivation but showed different patterns during linear growth: I. cangae showed faster leaf development but was slower on sprout production than I. serracarajensis. The mechanism of leaf expansion is related to plasma membrane $\mathrm{H}^{+}$-ATPase activation, near to 2-fold higher in $I$. cangae. On the other hand, the effective quantum yield of photosystem II was higher in $I$. serracarajensis than in $I$. cangae. During the cultivation, new sporophytes of $I$. cangae were produced, confirming its reproductive status. We have also tested elevated iron levels on the growth of plants, but no interference of iron concentration was observed. The results of this work have broad applicability, assisting other low-cost cultivation studies, which are very important in ecosystem recovery of mining areas and conservation strategies.

Key-words: Amazon; rare species; lagoon; photosynthesis; leaf expansion 


\section{INTRODUCTION}

The Isoetaceae family is composed of a single genus, Isoetes L., which comprises about 350 species (James Hickey et al., 2006). They are mainly aquatic or semi-aquatic of oligotrophic lagoons and slow streams, although some species grow in wet soil that dries in the summer. In Brazil, 25 species of Isoetes were identified (Pereira et al., 2016; Prado et al., 2015). Recently, two new endemic species in Brazilian Amazon were described: Isoetes cangae and Isoetes serracarajensis (Pereira et al., 2016; Santos et al., 2019). These two species distinguish from each other and other Amazon Basin species in traits of the megaspores (female spores) (Pereira et al., 2016), usually considered in this group phylogeny. However, the more interesting aspect about these species is the habitat occurrence of these two species in Serra de Carajás, Pará state, more specifically in ferruginous plateaus of the Carajás mountain range. This environment presents extremely conditions such as acid and oligotrophic soil with high concentrations of heavy metals, high temperatures, and strong seasonality, with a well-defined dry season (Gagen et al., 2019). I. cangae is an aquatic plant endemic to only one lagoon in the ferruginous fields of the south of Serra dos Carajás while $I$. serracarajensis is an amphibious species found in several ferruginous plateaus, in seasonally flooded environments.

The ontogeny of $I$. cangae plants and a protocol for reproduction was studied based on in vitro culture of megaspores and microspores in order to obtain viable sporelings (Caldeira et al., 2019). However, knowledge about the species traits and strategies related to habitat occupation, growth, 
survival, and reproduction in this harsh environment is fundamental for the conservation biology of Isoetes, and site restoration strategies.

In the present study, we aimed to establish the ex-situ cultivation of both $I$. cangae and $I$. serracarajensis while we explore and compare their physiological aspects related to nutrition, growth, and photosynthesis. We were able to establish a successful protocol for the outdoors's ex-situ growth for both species. Besides, we provide some insights and discussion about physiological traits, which can be used as markers for ecophysiological performance for these Isoetids, such as the chlorophyll fluorescence and the plasma membrane $\mathrm{H}^{+}$-ATPase activity.

\section{MATERIAL AND METHODS}

\subsection{Plant Site and Material}

The two Isoetes species studied were endemic from Serra dos Carajás, in the southeast of the Amazon region and the Pará State, northern Brazil. Serra dos Carajás comprises north and south ranges (Serra Norte and Serra Sul, respectively), located above $700 \mathrm{~m}$ in altitude. Two conservation units were created by the Federal Government of Brazil to protect the Carajás mountain range: the Carajás National Forest (FLONA) and the National Park of "Campos Ferruginosos" (Ferruginous Fields). These protected areas include extensive areas of canga (superficial iron crust that occurs over ferriferous rocks) that hosts several endemic plant species just recently studied in exquisite detail (Nunes et al., 2018; Santos et al. 2019). Plants of $I$. cangae and I. serracarajensis were collected in the summer of 2018 (February), from different sites, according to Figure 1, to represent all the 
genetic and morphological diversity found in the FLONA. I. cangae is restricted to one lagoon called Amendoim (6²3' 51.81" S - 50²2 20.88” W) while $I$. serracarajensis has a spread distribution along several pounds at ferruginous plateaus of Carajás Mountain range (Figure 1).

Vouchers of studied populations can be found at the Herbarium of the Federal University of Rio de Janeiro, RFA (RFA 41140 to 41142, I. cangae, and RFA 41143). Collecting permits were granted by Instituto Chico Mendes de Biodiversidade do Ministério do Meio Ambiente (ICMBio/MMA; n. 59724).

\subsection{Water and Soil Analysis}

Sediment samples for nutrient determination were taken in 2018 during both wet and dry seasons. During campaigns, we also take water for nutrient determination at a depth of $0.5 \mathrm{~m}$ in the lagoon and at the pond water surface where we found $I$. serracarajensis. The following parameters were analyzed in both sediments and water samples: $\mathrm{pH}$, organic matter $(\mathrm{OM})$, total $\mathrm{N}$ (nitrogen), P (phosphorus), K (potassium) and total Fe (iron), Zn (zinc), Mn (manganese), and $\mathrm{Cu}$ (copper). Organic matter was determined using the method described by Walkley and Black (1934), total $\mathrm{N}$ was determined by the Kjeldahl method and total P by the colorimetric method (Yoshida et al., 1971). The concentrations of $\mathrm{K}, \mathrm{Mn}$, and $\mathrm{Cu}$ in tailings were determined by digestion with concentrated $\mathrm{HNO}_{3}$ and $\mathrm{HClO}_{4}$ (3:1) and analyzed through Inductively Coupled Plasma Emission Spectroscopy (ICPE-9000, Shimadzu).

\subsection{Plant ex-situ Cultivation}


Plants of both species were collected in the natural habitat and transferred to a greenhouse for monitoring the plant growth and the parameters of water quality in the new artificial environment. After collect, plants were washed to remove the substrate from the original collection sites then were conditioned in plastic pots with tap water before transporting to the

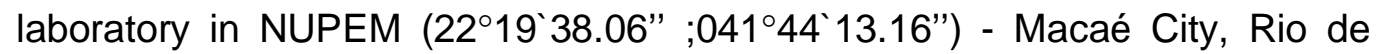
Janeiro State, Brazil).

In laboratory I. cangae and I. serracarajensis were placed in thirty (30) previously prepared plastic beakers (2L) containing fifty milliliters of tap water, $6.21 \mathrm{~g}$ of organic substrate (sphagnum peat) in the bottom and $21 \mathrm{~g}$ of quartzite sand on top. The chemical parameters of the substrate are presented in table 1. Fifty (50) I. cangae specimens were distributed in 25 beakers, two plants in each. Ten (10) specimens of $I$. serracarajensis were placed in five (5) beakers similarly prepared the set of I cangae. The experimental sets of beakers were kept in the greenhouse with natural light conditions.

\subsection{Plant Pruning and Growth Monitoring}

Plant specimens of similar size were selected for the cultivation experiment. At the beginning of the experiment, the specimens were pruned to ensure better standardization and to facilitate the detection and measurement of new leaves.

Afterward, a regular monitoring protocol was carried out every three days during 40 days in 3 seasons (autumn, winter, and spring). After each period of 40 days, plants were pruned again, and the regrowth was monitored. Plants were evaluated daily for general conditions and growth of 
microorganisms. Monitoring protocol considers the registration of new leaves by counting and length measurements. Besides, we recorded plant conditions with a photographic apparatus, controlling focal distance, exposure, speed, and other photographic parameters.

The water physicochemical characteristics $(\mathrm{pH}$, temperature, conductivity, salinity, dissolved solids content, percentage of oxygen saturation, and dissolved oxygen rate) and climate parameters (temperature, humidity, and luminosity) were also recorded.

\subsection{Plant Nutrients Analysis}

All leaves pruned were used to evaluate the concentrations of nutrients through inductively coupled plasma spectrometry. Isoetes leaves were harvested, washed, drying, and digested with concentrated $\mathrm{HNO}_{3}$ and $\mathrm{HClO}_{4}$ (3:1) to be analyzed. The analyses were performed using an Inductively Coupled Plasma Emission Spectroscopy (ICPE-9000, Shimadzu).

\subsection{Plant Tolerance to Iron}

To evaluate the $I$. cangae and $I$. serracarajensis tolerance to different concentrations of soluble iron, we exposed both to four different concentrations of Fe-EDTA added in the water (0.00 - control, 0.20, 0.60 and $1.80 \mathrm{mg} / \mathrm{L})$. The concentrations were used based on natural total iron concentration in-situ (table 2). This experiment was carried out in 16 beakers, 4 per treatment, assembled similarly to the beakers used to evaluate the growing pattern. Each beaker contained three plants. Measurements of growth and sprouting and assessments of water characteristics were carried 
out every seven days. The results presented are representative from one season (end of winter - August).

\subsection{Plasma membrane-enriched vesicles}

Plasma membrane (PM) vesicles were isolated from Isoetes leaves using differential centrifugation as described by (Zandonadi et al., 2010) with some modifications. Briefly, about $5 \mathrm{~g}$ (fresh weight) of Isoetes leaves was homogenized using a mortar and pestle in $6 \mathrm{~mL}$ of ice-cold buffer containing $250 \mathrm{mM}$ sucrose, 10\% (w/v) glycerol, 0.5\% (w/v) PVP (PVP-40, 40 kDa), 2 mM EDTA, 0.2\% (w/v) BSA, and 0.1 M Tris- $\mathrm{HCl}$ buffer, $\mathrm{pH}$ 7.6. Just before use, $150 \mathrm{mM} \mathrm{KCl}, 2 \mathrm{mM}$ DTT, and $1 \mathrm{mM}$ PMSF were added to the buffer. The homogenate was strained through four layers of cheesecloth and centrifuged at $1,500 \mathrm{~g}$ for $10 \mathrm{~min}$. The supernatant was centrifuged at $8,000 \mathrm{~g}$ for $10 \mathrm{~min}$ and then at $100,000 \mathrm{~g}$ for $40 \mathrm{~min}$. The pellet was resuspended in a small volume of ice-cold buffer containing $10 \mathrm{mM}$ MES-BTP, $\mathrm{pH} 7.5,10 \%$ (v/v) glycerol, $1 \mathrm{mM}$ DTT, and $1 \mathrm{mM}$ EGTA. The vesicles were either used immediately or frozen under liquid $\mathrm{N}_{2}$ and stored at $-80^{\circ} \mathrm{C}$ until use. All procedures were carried out below $4^{\circ} \mathrm{C}$. Protein concentrations were determined by the method of (Bradford, 1976).

\subsection{Plasma membrane $\mathrm{H}^{+}$-ATPase activity}

The hydrolytic $\mathrm{H}^{+}$-ATPase activity in PM vesicles was determined by measuring the release of Pi colorimetrically as described in Zandonadi et al. (2010). In Isoetes cangae plants between 70 and $80 \%$ of the $\mathrm{PM}$ vesicle $\mathrm{H}^{+}-$ ATPase activity measured at $\mathrm{pH} 6.5$, was inhibited by $0.1 \mathrm{mM}$ sodium 


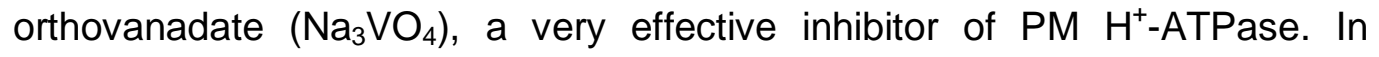
Isoetes serracarajensis plants, only $30-40 \%$ of the PM vesicle $\mathrm{H}^{+}$-ATPase activity was inhibited by $\mathrm{Na}_{3} \mathrm{VO}_{4}$. The assay medium consisted of $1 \mathrm{mM} \mathrm{A}$ TP-BTP, 5 mM MgSO 4,10 mM MOPS-BTP (pH 6.5), 100 mM KCl, 0.2 mM $\mathrm{Na}_{2} \mathrm{MoO}_{4}$ and $0.05 \mathrm{mg} \mathrm{mL}^{-1}$ vesicle protein.

\subsection{Chlorophyll a fluorescence}

\subsubsection{Pulse-Amplitude-Modulated (PAM) fluorometry}

In order to compare the photosynthetic performance of the two studied Isoetes species regarding leaf exposition to air, the effective quantum yield of photosystem II ( $\triangle F / F m$ ', or PSIl efficiency) was accessed with a portable pulse amplitude fluorometer (mini-PAM, Walz, Germany). The photosynthetic performance of the two studied Isoetes species consider two points in the same leaf, below and above the waterline. The leaves were previously exposed to an irradiation $160 \mu \mathrm{mol}$ photons $\mathrm{m}^{-2} \mathrm{~s}^{-1}$ provided by the miniPAM's internal halogen lamp, which was plugged to power line during the measurements to keep the light intensity constant. This process avoids variations on the light microenvironment. The steady-state fluorescence, recorded at ambient light $(F)$ and the maximal fluorescence $\left(F m^{\prime}\right)$, recorded after a saturating light pulse $\left(800\right.$, PAR $>4000 \mu \mathrm{mol}$ photons $\left.\mathrm{m}^{-2} \mathrm{~s}^{-1}\right)$, were used to calculate $\Delta F / F m^{\prime}$, (where $\Delta F=F m^{\prime}-F$ ) (Genty et al., 1989; Schreiber et al., 1995). Light intensity was recorded using the quantum sensor localized at the mini-PAM's leaf-clip.

\subsubsection{Chlorophyll a fluorescence Imaging}


Images of the effective quantum yield of photosystem II ( $\left.\Phi_{\mathrm{PS} I I}\right)$ were undertaken using an imaging system developed to work as described in (Duarte et al., 2005; Duarte and Lüttge, 2007; Rascher et al., 2000). Four arrays of 36 blue light provided the photosynthetic and excitation lightsemitting diodes ( $\lambda=470 \mathrm{~nm}$, maximum power 432 Watts), the intensity of which was micro-controlled by pulse-width modulation at a frequency of 1200 $\mathrm{Hz}$. During the experiments, the light intensity was kept constant at $200 \mu \mathrm{mol}$ photons $\mathrm{m}^{-2} \mathrm{~s}^{-1}$. Chlorophyll fluorescence was selectively detected by a Peltier-cooled digital camera Alta U6 (Apogee Inc, USA), equipped with a CCD sensor of $1024 \times 1024$ pixels and 16-bit digitalization. $A \lambda<665$ filter RG655 Schott (Mainz, Germany) was attached to the camera objective (60 mm macro lens, Nikkor, USA). Images of chlorophyll fluorescence were recorded and processed on a PC by customized software written in Visual $\mathrm{C}^{++}$. $\Phi_{\mathrm{PSII}}$ was recorded according to the saturating light pulse method (Genty et al., 1989; Schreiber et al., 1995). First, an image of the sample steady-state fluorescence (iF) under constant light intensity was recorded. After that, a saturating light pulse (intensity: $\sim 3000 \mu \mathrm{mol}$ photons $\mathrm{m}^{-2} \mathrm{~s}^{-1}$, duration: $800 \mathrm{~ms}$ ) was applied over the algal samples. The last $150 \mathrm{~ms}$ of this pulse was used to integrate the maximal fluorescence signal of the second image (iFm). Both iF and iFm (integer 16-bitts images) were corrected by dividing them by the pixel mean of a fluorescence standard (Walz, Germany) placed inside the image field. The resulting images (32-bits real point flow) were used to calculate the images of $i \Phi_{P S I I}$ were recorded every $20 \mathrm{~min}$ and calculated as $i \Phi_{P S I I}=(i F m$ e iF) / iFm. Posterior image processing for pixel average of individual sample 
and temporal dynamic was conducted with the software ImageJ (Abramoff et al., 2004).

\subsection{Statistical analysis}

Data were analyzed by ANOVA and Dunnett' $S$ test to determine the differences between treatments and controls. Regression analysis was performed on data of leaf growth and sprouting. For all statistical tests, $\mathrm{p}$ values $<0.05$ are considered statistically significant.

\section{RESULTS}

During the growth period of the Isoetes plants, in autumn, winter, and spring, the air temperature was, on average, $23.3^{\circ} \mathrm{C}, 23.8^{\circ} \mathrm{C}$, and $24.8^{\circ} \mathrm{C}$, respectively. The relative humidity was, on average, $78.6 \%, 73.4 \%$, and $77.4 \%$, respectively.

The water characteristics of the lagoon of Isoetes cangae and the pond of Isoetes serracarajensis are presented in table 1. Ponds and the studied lagoon distinguish in Boron (B), Aluminum (AI), Electric conductivity (EC), Phosphorous (P), Potassium (K), Magnesium (Mg), Ferrous (Fe), Sulfur (S), and Potential hydrogenionic $(\mathrm{pH})$. The substratum characteristics from the original sites of each species are were distinct for all variables considered (Table 2).

Both species growth and reproduce in an artificial media developed. The cost of the cultivation system was around US\$ 0.15 per plant, considering the following materials: sand, sphagnum peat, and beakers. The chemical characteristics of the organic substrate used in the cultivation of Isoetes 
cangae and Isoetes serracarajensis are showed in Table 3, with values of Organic Matter, Total N, Total Organic Carbon and macro and micronutrients $\left(\mathrm{NH}_{4}{ }^{+}, \mathrm{P}, \mathrm{K}, \mathrm{Ca}, \mathrm{Mg}, \mathrm{S}, \mathrm{B}, \mathrm{Cu}, \mathrm{Fe}, \mathrm{Mn}, \mathrm{Zn}\right)$. Plant nutrition was accessed by quantifying leaves mineral concentration in both species (Table 4). I. cangae from Serra dos Carajás presented higher N, P, S, Cu, Fe, Mn, and Al than plants from ex-situ cultivation. Comparing I. cangae and I. serracarajensis, the later always presented enhanced mineral content as compared with the former.

The water physicochemical characteristics in the beakers during the analyzed period remained very similar between the two species of Isoetes. The temperature dropped gradually from the third day when it was $27^{\circ} \mathrm{C}$ reaching the minimum point on the 12 th day, with $20 \stackrel{\circ}{C}$ for both species. After the $15^{\text {th }}$ day, temperature values increase until they return to $27^{\circ} \mathrm{C}$ for $I$. cangae and reaching $26^{\circ} \mathrm{C}$ in $I$. serracarajensis water (Figure 2). The $\mathrm{pH}$ in the beckers was slightly more acidic in $I$. cangae ( $\mathrm{pH} 6.58$ ) than in $I$. serracarajensis $(\mathrm{pH} 6.92)$ at the beginning of the monitoring, but the values showed an abrupt increase in the sixth day (7.49 in I. cangae and 7.90 in $I$. serracarajensis) (Figure 3). From 12th day values were slightly higher in $I$. cangae (7.60) than in I. serracarajensis and later remained stable until the end of observations, on the 18th day. Conductivity showed a typical pattern in evaluated species, showing a gradual increase until the ninth day, when the conductivity was higher in $I$. cangae, falling on the 12 th day when the conductivity becomes higher in $I$. serracarajensis (Figure 2). The values were stable at the end of the observations. Salinity did not change throughout the evaluation period, maintained at $0.1 \mathrm{ppt}$. Total dissolved solids had a gradual 
increase in both species until the 12th day; however, on the 15th day, these values decreases a little, mainly I. cangae (Figure 2). The levels of dissolved $\mathrm{O}_{2}$ and $\mathrm{O}_{2}$ saturation in water are quite different about the two species. $I$. cangae varied from $7.1 \mathrm{mg} / \mathrm{L}$ and $89.4 \%$ saturation on the third day, reaching $9.59 \mathrm{mg} / \mathrm{L}$ and $118.4 \%$ at the end of the experiment. I. serracarajensis presented values of $8.63 \mathrm{mg} / \mathrm{L}$ and $108.18 \%$ of saturation on the third day, ranging up to $9.23 \mathrm{mg} / \mathrm{L}$ and $113.58 \%$ saturation on day 8 .

Plants of $I$. serracarajensis had a lower sprouting rate as compared to I. cangae in the first six days (Figure 2). The rates are similar on days 9 , and 12 days, however $I$. serracarajensis has a budding rate approximately three times higher than $I$. cangae in the final evaluation period. An inverse pattern was observed considering plant heights, I. serracarajensis presenting moderate growth with a gain of only $1 \mathrm{~cm}$ over the period evaluated, whereas I. cangae presents an approximately $3 \mathrm{~cm}$ growth during the period evaluated (Figure 3). I. serracarajensis are too short of reaching above the waterline. In the field, these plants are resistant to suddenly dry.

On the other hand, I. cangae only survives in one lagoon, always submerged. However, during ex-situ cultivation, I. cangae leaves were able to survive above the waterline. Here, we first report this remarkable trait. We experimented with reducing the water suddenly, but leaves shrink in a few minutes.

The leaf growth rate of $I$. cangae was $0.191 \mathrm{~cm}$ per day, while $I$. serracarajensis was $0.042 \mathrm{~cm}$ per day. These results are in confidence with biochemistry differences between the species, while I. cangae plants presented higher plasma membrane $\mathrm{H}^{+}$-ATPase activity as compared to $I$. 
serracarajensis (Figure 4). This enzyme plays a central role in the majority of plant processes, such as tissue expansion, nutrient acquisition, stress tolerance, and others (Falhof et al. 2016). The leaf elongation correlates to higher values of $\mathrm{H}^{+}$-ATPase activity (Figures 2 and 3).

Photosynthetic performance of the two Isoetes species evaluated thought the PSII efficiency was also distinct, I. serracarajensis PSIl efficiency is near to $20 \%$ higher the $I$. cangae (Figures 5 and 6 ). I. cangae is only found submerged in permanent lagoons over "canga" soil, while I. serracarajensis is also found terrestrial on wet soil in addition to submerged (Pereira et al., 2016). Chlorophyll a fluorescence is considered a useful indicator of light reactions of photosynthesis (Rascher et al., 2000) and the photochemical efficiency of photosystem II can be assessed by PAM fluorometers (Schreiber et al., 1975). Data obtained have no precedence in the bibliography. To the best of our knowledge, the only work addressing PSII efficiency in Isoetes genus was published by Hawes and collaborators (Hawes et al., 2003). Herein we present the first report of PSIl efficiency of these two new Amazon quillworts.

The leaf position to the waterline did not interfere in the PSII efficiency (Figure 5). The PSII efficiency of $I$. serracarajensis is near to $20 \%$ higher than the $I$. cangae. The values were 0.33 in $l$. serracarajensis and 0.27 in $I$. cangae. The results are hard to compare because our plants were cultivated ex-situ at $12 \mathrm{~cm}$ water depth, while I. alpinus plants were measured in-situ in 3-7 $\mathrm{m}$ depth. However, our results were in the range of 0.02 to 0.80 reported by (Hawes et al., 2003). 
Different concentrations of iron (FeEDTA $0.20 ; 0.60$ and $1.80 \mathrm{mg} / \mathrm{L}$ ) than the observed in natural conditions $(0.55 \mathrm{mg} / \mathrm{L}$ of iron in the habitat of Isoetes cangae) did not alter the growth parameter as measured by sprouting and leaf length (Figure 8 ). The sprouting rate was 0.089 per day on average in the different Fe concentrations. The leaf growth rate was $0.13 \mathrm{~cm}$ per day on average in the different iron concentrations.

The sporophytes derived from ex-situ plants were able to growth in an artificial pool in Serra dos Carajás and near to $80 \%$ of plants survived planting in the lagoon after four months. 


\section{DISCUSSION}

Generally, the water physicochemical characteristics in natural habitats and beakers of both species were very similar, but some parameters varied between the species. These parameters seem to be a critical started point to understand the ecology and physiology of Isoetes. A study reported the water chemistry and the distribution of the endangered aquatic quillwort Isoetes sinensis in China as a determinant for the distribution and occurrence of that species (Wen et al., 2003). However, the definition of a typical isoetid environment it is not quite simple (Boston and Adams, 1987; Smolders et al., 2002), because of the inherent geochemistry difference of the sites.

Values of total $\mathrm{N}, \mathrm{B}, \mathrm{Al}, \mathrm{P}, \mathrm{Ca}, \mathrm{Cu}, \mathrm{Mn}, \mathrm{Zn}$, and $\mathrm{S}$ in the lagoon of Isoetes cangae are very similar to the ponds of Isoetes serracarajensis. However, the ponds are more abundant in $\mathrm{K}$ (120-fold), Fe (2.4-fold), and Ca (2.0-fold), and more deficient in $\mathrm{Na}(40 \%$ less). Also, the pond water has a 6 fold higher electric conductivity and a slightly higher $\mathrm{pH}$ than the lagoon of $I$. cangae. Wen et al. (2003), studying aquatic quillwort Isoetes sinensis in China, reported higher values of total $\mathrm{P}, \mathrm{Ca}, \mathrm{Mg}, \mathrm{Mn}$, and $\mathrm{Zn}$. Higher levels of water $\mathrm{Ca}$ and $\mathrm{Mg}$ was also observed in lagoons from North America with Isoetes macrospora (Boston and Adams, 1987). We have reported here a higher level of iron dissolved as expected due to the vast iron ore deposits of our study site (Gagen et al., 2019).

Isoetids are found from sandy, low-nutrient, and low-organic sediments to high-organic, clay-rich sediment (Sand-Jensen and Søndergaard, 1978; Wilson and Keddy, 1985). Here the sediment of original sites of each species was characterized. and the values of $\mathrm{P}, \mathrm{Na}, \mathrm{B}, \mathrm{Co}, \mathrm{Fe}, \mathrm{Mn}$, and $\mathrm{Zn}$ were 
higher in the pond as compared to the lagoon (Table 3). Instead, organic matter, $\mathrm{K}, \mathrm{Ca}$, and $\mathrm{Mg}$ were higher in the lagoon. The pond dries seasonably, corroborating for the lower content of organic matter. Additionally, the lagoon has organic inputs from sources composed primarily of palms and macrophytes (Sahoo et al., 2016). The enormous Fe concentration is a reflex of the geochemistry of this enriched $\mathrm{Fe}_{2} \mathrm{O}_{3}$ sediment.

This work demonstrated that a simple cultivation system could be applied for ex-situ conservation for both Isoetes cangae and Isoetes serracarajensis. We do not find differences in plant growth on different seasons; however, we register variations on PAR average values, so Isoetes plants appeared to adapt very quickly to radiation changes. The $\mathrm{pH}$ of water of $I$. cangae plants was lower as compared to the $I$. serracarajensis at the begging of the experiments. At the end of the monitoring, the water of both species presented a similar pH. Very little is known about Isoetes habitat in the tropics, but they were found in water with a wide $\mathrm{pH}$ range from 5.1 to 8.51 in Europe, North America and Asia (Abeli et al., 2012; Boston and Adams, 1987; Chappuis et al., 2011; Wen et al., 2003). The $\mathrm{O}_{2}$ parameters of the water were initially higher in beckers of $I$. serracarajensis than those of $I$. cangae`s. The majority of the literature does not present $\mathrm{O}_{2}$ data. The dissolved $\mathrm{O}_{2}$ in the water had varied from 6.07 to $7.47 \mathrm{mg} / \mathrm{L}$ in four study sites of Isoetes sinensis in China (Wen et al., 2003). The dissolved $\mathrm{O}_{2}$ in the water of the original site of / cangae is $7.75 \mathrm{mg} / \mathrm{L}$ on average (data not shown).

Since the organic matter did not appear to be constraint and it was previously used for in vitro cultivation of Isoetes cangae (Caldeira et al., 2019), we have used an organic substrate based on sphagnum peat and 
covered with sand that supplied plants effectively (Table 3). Generally, macronutrients were higher in the artificial substrate, while micronutrients were lower in the substrate.

Plants of $I$. cangae from the field presented tissue nutrient concentrations higher than plants of ex-situ cultivation system overall, except for $\mathrm{Ca}$ and $\mathrm{B}$ (table 2). The accumulation of metals such as $\mathrm{Cu}, \mathrm{Fe}$, and $\mathrm{Mn}$ in both species in the natural environment is notably higher than an artificial system. Considering soluble Fe concentration in the water, the most contrasting element concentration between habitats of isoetids plants described in bibliography and I. cangae e I serracarajensis, the soluble iron had not influenced the growth parameter as measured by sprouting and leaf length. However, iron concentrations in plant leaves are remarkably high. To the best of our knowledge, no other plant was ever described with such Fe accumulation capacity. I. cangae was able to accumulate $16,950 \mathrm{mg} / \mathrm{kg}$ total Fe and I. serracarajensis $33,050 \mathrm{mg} / \mathrm{kg}$ total Fe. Isoetes anatolica from seasonal ponds of Turkey can accumulate $431.00 \mathrm{mg} / \mathrm{kg}$ of Fe (Ozyigit et al., 2013). Here plant macronutrients were also evaluated, and $I$. serracarajensis presented more $\mathrm{N}, \mathrm{P}, \mathrm{K}, \mathrm{Ca}, \mathrm{Mg}$, and $\mathrm{S}$ than $\mathrm{I}$. cangae. It is rare data of plant nutrition in Isoetes. It was reported in Isoetes lacustris from the Lagoon Baciver in Spanish Pyrenees a range of $2.0-2.6 \% \mathrm{~N}$ and $0.14-0.26 \% \mathrm{P}$ (Gacia and Ballesteros, 1994). I. lacustris from Loch Brandy, Scotland, presented $1.8 \% \mathrm{~N}$ and $0.02 \% \mathrm{P}$ (Richardson et al., 1984).

The leaves of $I$. cangae grown faster than $I$. serracarajensis. The leaf elongation might be associated with higher values of $\mathrm{H}^{+}$-ATPase activity (Figures 3 and 4). The regulation of $\mathrm{H}^{+}$-ATPase activity is closely related to 
tissue elongation through acid growth (Dünser and Kleine-Vehn, 2015). Most of the data is related to land plants, but similar mechanisms have been shown in aquatic plants (Koizumi et al., 2011). Plasma membrane $\mathrm{H}^{+}$-ATPase plays a central role in the majority of plant processes, such as tissue expansion, nutrient acquisition, stress tolerance, and others (Falhof et al., 2016). Ion transport studies in aquatic plants are rare (Babourina and Rengel, 2010; Baur et al., 1996), and our findings may contribute to understanding part of the mechanisms relying on aquatic plant health and development.

Monitoring enzymes activity in field conditions is unpractical. For field assessment of Isoetes's health, the use of photochemical efficiency is a more practical ecoindicator. Chlorophyll a fluorescence is considered a useful indicator of light reactions of photosynthesis (Rascher et al., 2000) and the photochemical efficiency of photosystem II (PSII) can be assessed by PAM fluorometers(Schreiber et al., 1975). The photosynthetic performance of the two Isoetes species was evaluated through the PSII efficiency. To the best of our knowledge, the only work addressing PSIl efficiency in Isoetes genus was published by Hawes and collaborators (Hawes et al., 2003). Herein we present the first report of PSII efficiency of these two new Amazon quillworts. The results are hard to compare because our plants were cultivated ex situ at $12 \mathrm{~cm}$ water depth, while I. alpinus plants were measured in-situ in 3-7 m depth. However, our results were in the range of the values reported by Hawes et al., (2003).

The data presented illustrate that both species can grow and reproduce in a artificial low-cost media composed by commercial organic substrate, sand, and tap water. Here, we first report the ex-situ cultivation of Isoetes in 
outdoor conditions. It is presented a very feasible protocol, where critical

physiological aspects of plant growth were monitored. The technics employed

here and the characteristics evaluated during ex-situ cultivation are relevant

for understanding both the ecological and physiological traits of Isoetes. The

results of this work have broad applicability, assisting other low-cost ex situ

cultivation studies as an essential strategy for isoetids conservation.

\section{REFERENCES}

Abeli, T., Barni, E., Siniscalco, C., Amosso, C., Rossi, G., 2012. A costeffective model for preliminary site evaluation for the reintroduction of a threatened quillwort. Aquat. Conserv. Mar. Freshw. Ecosyst. 22, 66-73. https://doi.org/10.1002/aqc.1246

Abeli, T., Cauzzi, P., Rossi, G., Pistoja, F., Mucciarelli, M., 2018. A gleam of hope for the critically endangered Isoëtes malinverniana: Use of smallscale translocations to guide conservation planning. Aquat. Conserv. Mar. Freshw. Ecosyst. 28, 501-505. https://doi.org/10.1002/aqc.2848

Abramoff, M.D., Magalhães, P.J., Ram, S.J., 2004. Biophotonics international. Biophotonics Int. 11, 36-42. https://doi.org/10.1201/9781420005615.ax4

Babourina, O., Rengel, Z., 2010. Ion transport in aquatic plants, in: Waterlogging Signalling and Tolerance in Plants. https://doi.org/10.1007/978-3-642-10305-6_11

Baur, M., Meyer, A.J., Heumann, H.G., Lützelschwab, M., Michalke, W., 1996. Distribution of plasma membrane $\mathrm{H}+$-ATPase and polar current patterns in leaves and stems of Elodea canadensis. Bot. Acta. https://doi.org/10.1111/j.1438-8677.1996.tb00587.x

Boston, H.L., Adams, M.S., 1987. Productivity, Growth and Photosynthesis of Two Small 'Isoetid' Plants, Littorella Uniflora and Isoetes Macrospora. J. Ecol. 75, 333. https://doi.org/10.2307/2260422

Bradford, M.M., 1976. A rapid and sensitive method for the quantitation of microgram quantities of protein utilizing the principle of protein-dye binding. Anal. Biochem. 72, 248-254. https://doi.org/10.1016/00032697(76)90527-3

Caldeira, C.F., Abranches, C.B., Gastauer, M., Ramos, S.J., Guimarães, J.T.F., Pereira, J.B.S., Siqueira, J.O., 2019a. Sporeling regeneration and ex situ growth of Isoëtes cangae (Isoetaceae): Initial steps towards the conservation of a rare Amazonian quillwort. Aquat. Bot. https://doi.org/10.1016/j.aquabot.2018.10.001

Caldeira, C.F., Abranches, C.B., Gastauer, M., Ramos, S.J., Guimarães, J.T.F., Pereira, J.B.S., Siqueira, J.O., 2019b. Sporeling regeneration and ex situ growth of Isoëtes cangae (Isoetaceae): Initial steps towards the conservation of a rare Amazonian quillwort. Aquat. Bot. 152, 51-58. https://doi.org/10.1016/j.aquabot.2018.10.001

Chappuis, E., Ballesteros, E., Gacia, E., 2011. Temporary emersion enhances 
amphibious Isoetes production. Limnetica 29, 373-384.

https://doi.org/10.23818/limn.35.30

Duarte, H.M., Geßler, A., Scarano, F.R., Franco, A.C., De Mattos, E.A., Nahm, M., Rennenberg, H., Pena Rodrigues, P.J.F., Teixeira Zaluar, H.L., Lüttge, U., 2005. Ecophysiology of six selected shrub species in different plant communities at the periphery of the Atlantic Forest of SEBrazil. Flora Morphol. Distrib. Funct. Ecol. Plants 200, 456-476. https://doi.org/10.1016/j.flora.2005.02.004

Duarte, H.M., Lüttge, U., 2007. Correlation between photorespiration, CO2assimilation and spatiotemporal dynamics of photosynthesis in leaves of the C3- photosynthesis/crassulacean acid metabolism-intermediate species Clusia minor L. (Clusiaceae). Trees - Struct. Funct. 21, 531-540. https://doi.org/10.1007/s00468-007-0146-y

Dünser, K., Kleine-Vehn, J., 2015. Differential growth regulation in plants-the acid growth balloon theory. Curr. Opin. Plant Biol. https://doi.org/10.1016/j.pbi.2015.08.009

Falhof, J., Pedersen, J.T., Fuglsang, A.T., Palmgren, M., 2016. Plasma Membrane $\mathrm{H}+-$ ATPase Regulation in the Center of Plant Physiology. Mol. Plant 9, 323-337. https://doi.org/10.1016/j.molp.2015.11.002

Gacia, E., Ballesteros, E., 1994. Production of Isoetes lacustris in a Pyrenean lake: seasonality and ecological factors involved in the growing period. Aquat. Bot. 48, 77-89. https://doi.org/10.1016/0304-3770(94)90074-4

Gagen, E.J., Levett, A., Paz, A., Gastauer, M., Caldeira, C.F., Valadares, R.B. da S., Bitencourt, J.A.P., Alves, R., Oliveira, G., Siqueira, J.O., Vasconcelos, P.M., Southam, G., 2019. Biogeochemical processes in canga ecosystems: Armoring of iron ore against erosion and importance in iron duricrust restoration in Brazil. Ore Geol. Rev. 107, 573-586. https://doi.org/10.1016/j.oregeorev.2019.03.013

Genty, B., Briantais, J.M., Baker, N.R., 1989. The relationship between the quantum yield of photosynthetic electron transport and quenching of chlorophyll fluorescence. Biochim. Biophys. Acta - Gen. Subj. 990, 8792. https://doi.org/10.1016/S0304-4165(89)80016-9

Hawes, I., Sutherland, D., Hanelt, D., 2003. The use of pulse amplitude modulated fluorometry to determine fine-scale temporal and spatial variation of in situ photosynthetic activity within an Isoetes-dominated canopy. Aquat. Bot. 77, 1-15. https://doi.org/10.1016/S03043770(03)00073-1

James Hickey, R., Macluf, C., Carl Taylor, W., 2006. A Re-evaluation of Isoetes savatieri Franchet in Argentina and Chile. Am. Fern J. 93, 126136. https://doi.org/10.1640/0002-8444(2003)093[0126:aroisf]2.0.co;2

Koizumi, Y., Hara, Y., Yazaki, Y., Sakano, K., Ishizawa, K., 2011. Involvement of plasma membrane $\mathrm{H}+$-ATPase in anoxic elongation of stems in pondweed (Potamogeton distinctus) turions. New Phytol. 190, 421-430. https://doi.org/10.1111/j.1469-8137.2010.03605.x

Ozyigit, I.I., Dogan, I., Eskin, B., Keskin, M., Demir, G., Yalcin, I.E., 2013. Mineral element uptake status of endemic Isoetes anatolica prada \& Rolleri populations from Bolu-Turkey. Pakistan J. Bot.

Pereira, J.B. d. S., Salino, A., Arruda, A., Stützel, T., 2016. Two New Species of Isoetes (Isoetaceae) from northern Brazil. Phytotaxa 272, 141-148. https://doi.org/10.11646/phytotaxa.272.2.5 
Prado, J., Sylvestre, L.D.S., Labiak, P.H., Windisch, P.G., Salino, A., Barros, I.C.L., Hirai, R.Y., Almeida, T.E., Santiago, A.C.P., Kieling-Rubio, M.A., Pereira, A.F.D.N., Ollgaard, B., Ramos, C.G.V., Mickel, J.T., Dittrich, V.A.O., Mynssen, C.M., Schwartsburd, P.B., Condack, J.P.S., Pereira, J.B.S., Matos, F.B., 2015. Diversity of ferns and lycophytes in Brazil. Rodriguesia 66, 1073-1083. https://doi.org/10.1590/21757860201566410

Rascher, U., Liebig, M., Lüttge, U., 2000. Evaluation of instant light-response curves of chlorophyll fluorescence parameters obtained with a portable chlorophyll fluorometer on site in the field. Plant, Cell Environ. https://doi.org/10.1046/j.1365-3040.2000.00650.x

Richardson, K., Griffiths, H., Reed, M.L., Raven, J.A., Griffiths, N.M., 1984. Inorganic carbon assimilation in the Isoetids, Isoetes lacustris $L$. and Lobelia dortmanna L. Oecologia 61, 115-121. https://doi.org/10.1007/BF00379096

Sahoo, P.K., Felix Guimarães, J.T., Martins Souza-Filho, P.W., Sousa da Silva, M., Maurity, C.W., Powell, M.A., Rodrigues, T.M., Fonseca da Silva, D., Mardegan, S.F., Furtini Neto, A.E., Dall'Agnol, R., 2016. Geochemistry of upland lacustrine sediments from Serra dos Carajás, Southeastern Amazon, Brazil: Implications for catchment weathering, provenance, and sedimentary processes. J. South Am. Earth Sci. 72, 178-190. https://doi.org/10.1016/j.jsames.2016.09.003

Sand-Jensen, K., Søndergaard, M., 1978. Growth and production of isoetids in oligotrophic Lake Kalgaard, Denmark. SIL Proceedings, 1922-2010 20, 659-666. https://doi.org/10.1080/03680770.1977.11896582

Santos, M.P., Victor, J., Araújo, R., De, A.V., Lopes, S., Cesar, J., Vettorazzi, F., Nunes, R., Calderón, E.N., Santana, M., Boechat, B., Abreu, F., Arêdes, S., Pereira, M.G., Campos, N.V., 2019. Genetic diversity by ISSR of two endemic quillworts ( Isoetes L .) species from Amazon Iron Rocky Outcrops, Isoetes cangae e I . serracarajensis.

Schreiber, U., Bilger, W., Neubauer, C., 1995. Chlorophyll Fluorescence as a Nonintrusive Indicator for Rapid Assessment of In Vivo Photosynthesis. Ecophysiol. Photosynth. 49-70. https://doi.org/10.1007/978-3-642-793547_3

Schreiber, U., Groberman, L., Vidaver, W., Schreiber, U., Groberman, L., Vidaver, W., 1975. Portable, solid-state fluorometer for the measurement of chlorophyll fluorescence induction in plants chlorophyll fluorescence induction in plants *. Rev. Sci. Instrum. 46, 538-542.

https://doi.org/10.1063/1.1134252

Smolders, A.J.P., Lucassen, E.C.H.E.T., Roelofs, J.G.M., 2002. The isoetid environment: Biogeochemistry and threats. Aquat. Bot. 73, 325-350. https://doi.org/10.1016/S0304-3770(02)00029-3

Wen, M.Z., Pang, X.A., Wang, Q.F., Taylor, W.C., 2003. Relationship between water chemistry and the distribution of the endangered aquatic quillwort isoetes sinensis palmer in China. J. Freshw. Ecol. 18, 361-367. https://doi.org/10.1080/02705060.2003.9663971

Wilson, S.D., Keddy, P.A., 1985. Plant Zonation on a Shoreline Gradient $\square$ : Physiological Response Curves of Component Species Author ( $\mathrm{s}$ ): Scott D. Wilson and Paul A. Keddy Published by $\square$ : British Ecological Society Stable URL $\square$ : https://www.jstor.org/stable/2260152 REFERENCES 
bioRxiv preprint doi: https://doi.org/10.1101/861351; this version posted December 3 2019. The copyright holder for this preprint (which was not certified by peer review) is the author/funder, who has granted bioRxiv a license to display the preprint in perpetuity. It is made available under aCC-BY-NC-ND 4.0 International license.

Linked ref 73, 851-860.

Zandonadi, D.B., Santos, M.P., Dobbss, L.B., Olivares, F.L., Canellas, L.P., Binzel, M.L., Okorokova-Façanha, A.L., Façanha, A.R., 2010. Nitric oxide mediates humic acids-induced root development and plasma membrane H+-ATPase activation. Planta 231. https://doi.org/10.1007/s00425-0101106-0 


\section{Tables and Figures}

Table 1. Water characteristics of original sites of Isoetes cangae and Isoetes serracarajensis

\begin{tabular}{llrr}
\hline Species & & I. serracarajensis & l. cangae \\
\hline Location & Pond & Lake \\
\hline $\mathrm{N}^{2} \mathrm{NH}_{4}{ }^{+}$ & $\mathrm{mg} / \mathrm{L}$ & 1.00 & 1.00 \\
$\mathrm{~N}^{-\mathrm{NO}_{3}}{ }^{-}$ & $\mathrm{mg} / \mathrm{L}$ & 0.00 & 0.00 \\
$\mathrm{~B}$ & $\mathrm{mg} / \mathrm{L}$ & 0.06 & 0.06 \\
$\mathrm{Al}$ & $\mathrm{mg} / \mathrm{L}$ & 1.84 & 2.16 \\
$\mathrm{EC}$ & $\mathrm{dS} / \mathrm{m}$ & 0.06 & 0.01 \\
$\mathrm{~N}$-total & $\mathrm{mg} / \mathrm{L}$ & 0.00 & 0.00 \\
$\mathrm{P}$ & $\mathrm{mg} / \mathrm{L}$ & 0.22 & 0.20 \\
$\mathrm{~K}$ & $\mathrm{mg} / \mathrm{L}$ & 18.00 & 0.15 \\
$\mathrm{Ca}$ & $\mathrm{mg} / \mathrm{L}$ & 0.20 & 0.20 \\
$\mathrm{Mg}$ & $\mathrm{mg} / \mathrm{L}$ & 0.04 & 0.02 \\
$\mathrm{Na}$ & $\mathrm{mg} / \mathrm{L}$ & 0.23 & 0.39 \\
$\mathrm{Cu}$ & $\mathrm{mg} / \mathrm{L}$ & 0.01 & 0.01 \\
$\mathrm{Fe}$ & $\mathrm{mg} / \mathrm{L}$ & 1.30 & 0.55 \\
$\mathrm{Mn}$ & $\mathrm{mg} / \mathrm{L}$ & 0.10 & 0.10 \\
$\mathrm{Zn}$ & $\mathrm{mg} / \mathrm{L}$ & 0.01 & 0.01 \\
$\mathrm{~S}$ & $\mathrm{mg} / \mathrm{L}$ & 1.67 & 1.66 \\
$\mathrm{pH}$ & - & 6.30 & 5.60 \\
\hline
\end{tabular}


bioRxiv preprint doi: https://doi.org/10.1101/861351; this version posted December 3,2019 . The copyright holder for this preprint (which was not certified by peer review) is the author/funder, who has granted bioRxiv a license to display the preprint in perpetuity. It is made available under aCC-BY-NC-ND 4.0 International license.

Table 2. Substrate characteristics of original sites of Isoetes cangae (lagoon) and Isoetes serracarajensis (pond).

\begin{tabular}{lcrr}
\hline Species & & I. serracarajensis & I. cangae \\
\hline Location & & Pond & Lake \\
\hline $\mathrm{P}$ & $\mathrm{mg} / \mathrm{kg}$ & 10.00 & 5.00 \\
$\mathrm{OM}$ & $\mathrm{g} / \mathrm{Kg}$ & 51.00 & 87.00 \\
$\mathrm{TOC}$ & $\mathrm{g} / \mathrm{Kg}$ & 30.00 & 50.00 \\
$\mathrm{pH}\left(\mathrm{CaCl}_{2}\right)$ & - & 4.60 & 4.00 \\
$\mathrm{pH}$ (buffer) & - & 5.47 & 4.97 \\
$\mathrm{~K}$ & $\mathrm{mg} / \mathrm{kg}$ & 35.19 & 50.83 \\
$\mathrm{Ca}$ & $\mathrm{mg} / \mathrm{kg}$ & 60.12 & 160.31 \\
$\mathrm{Mg}$ & $\mathrm{mg} / \mathrm{kg}$ & 12.15 & 48.61 \\
$\mathrm{~B}$ & $\mathrm{mg} / \mathrm{kg}$ & 0.73 & 0.56 \\
$\mathrm{Cu}$ & $\mathrm{mg} / \mathrm{kg}$ & 4.30 & 1.30 \\
$\mathrm{Fe}$ & $\mathrm{mg} / \mathrm{kg}$ & 1000.00 & 636.00 \\
$\mathrm{Mn}$ & $\mathrm{mg} / \mathrm{kg}$ & 11.70 & 1.00 \\
$\mathrm{Zn}$ & $\mathrm{mg} / \mathrm{kg}$ & 2.80 & 1.10 \\
\hline
\end{tabular}


Table 3. Substrate characteristics of ex situ cultivation medium of Isoetes cangae and Isoetes serracarajensis.

\begin{tabular}{ccr}
\hline Items & Unit & \multicolumn{1}{c}{ Value } \\
\hline $\mathrm{NH}_{4}{ }^{+}$ & $\mathrm{mg} / \mathrm{kg}$ & 96.20 \\
Total $\mathrm{N}$ & $\%$ & 1.38 \\
$\mathrm{P}$ & $\mathrm{mg} / \mathrm{kg}$ & 38.25 \\
& & \\
$\mathrm{~K}$ & $\mathrm{mg} / \mathrm{kg}$ & 44.50 \\
& & \\
$\mathrm{Ca}$ & $\mathrm{mg} / \mathrm{kg}$ & 29.80 \\
& & \\
$\mathrm{Mg}$ & $\mathrm{mg} / \mathrm{kg}$ & 14.90 \\
$\mathrm{~S}$ & $\mathrm{mg} / \mathrm{kg}$ & 43.02 \\
$\mathrm{~B}$ & $\mathrm{mg} / \mathrm{kg}$ & 6.33 \\
$\mathrm{Cu}$ & $\mathrm{mg} / \mathrm{kg}$ & 0.02 \\
$\mathrm{Fe}$ & $\mathrm{mg} / \mathrm{kg}$ & 0.76 \\
$\mathrm{Mn}$ & $\mathrm{mg} / \mathrm{kg}$ & 0.10 \\
$\mathrm{Zn}$ & $\mathrm{mg} / \mathrm{kg}$ & 0.04 \\
$\mathrm{Humidity}$ & $\%$ & 36.01 \\
$\mathrm{OM}$ & $\%$ & 67.19 \\
$\mathrm{Ash}$ & $\%$ & 32.81 \\
$\mathrm{EC}$ & $\mathrm{dS} / \mathrm{m}$ & 0.52 \\
$\mathrm{pH}$ & - & 6.30 \\
$\mathrm{OC}$ & $\%$ & 32.54 \\
$\mathrm{C} / \mathrm{N}$ & - & 24.00 \\
Density & $\mathrm{g} / \mathrm{cm}$ & 0.21 \\
\hline & &
\end{tabular}


Table 4. Leaf tissue mineral concentrations of Isoetes cangae and Isoetes serracarajensis in two sites of Serra dos Carajás, or in ex-situ cultivation.

\begin{tabular}{|c|c|c|c|c|c|}
\hline \multicolumn{2}{|c|}{ Species } & I. serracarajensis & I. cangae & I. serracarajensis & I. cangae \\
\hline \multicolumn{2}{|c|}{ Location } & Pond & Lake & \multicolumn{2}{|c|}{ Ex-situ cultivation } \\
\hline $\mathrm{N}$ & $\mathrm{g} / \mathrm{kg}$ & 32.55 & 28.73 & nd & 19.42 \\
\hline$P$ & $\mathrm{~g} / \mathrm{kg}$ & 2.28 & 1.97 & nd & 1.34 \\
\hline K & $\mathrm{g} / \mathrm{kg}$ & 46.00 & 10.10 & nd & 13.75 \\
\hline $\mathrm{Ca}$ & $\mathrm{g} / \mathrm{kg}$ & 3.75 & 3.00 & nd & 9.00 \\
\hline $\mathrm{Mg}$ & $\mathrm{g} / \mathrm{kg}$ & 2.83 & 1.89 & nd & 2.95 \\
\hline S & $\mathrm{g} / \mathrm{kg}$ & 2.45 & 2.45 & nd & 0.84 \\
\hline B & $\mathrm{mg} / \mathrm{kg}$ & 51.87 & nd & nd & 97.76 \\
\hline $\mathrm{Cu}$ & $\mathrm{mg} / \mathrm{kg}$ & 15.86 & 9.60 & nd & 4.50 \\
\hline $\mathrm{Fe}$ & $\mathrm{mg} / \mathrm{kg}$ & $33,050.00$ & $16,950.00$ & nd & 150.00 \\
\hline $\mathrm{Mn}$ & $\mathrm{mg} / \mathrm{kg}$ & 322.95 & 135.65 & nd & 120.00 \\
\hline $\mathrm{Al}$ & $\mathrm{mg} / \mathrm{kg}$ & $1,080.00$ & 980.00 & nd & 184.15 \\
\hline $\mathrm{Zn}$ & $\mathrm{mg} / \mathrm{kg}$ & 78.00 & 40.75 & nd & 76.00 \\
\hline
\end{tabular}




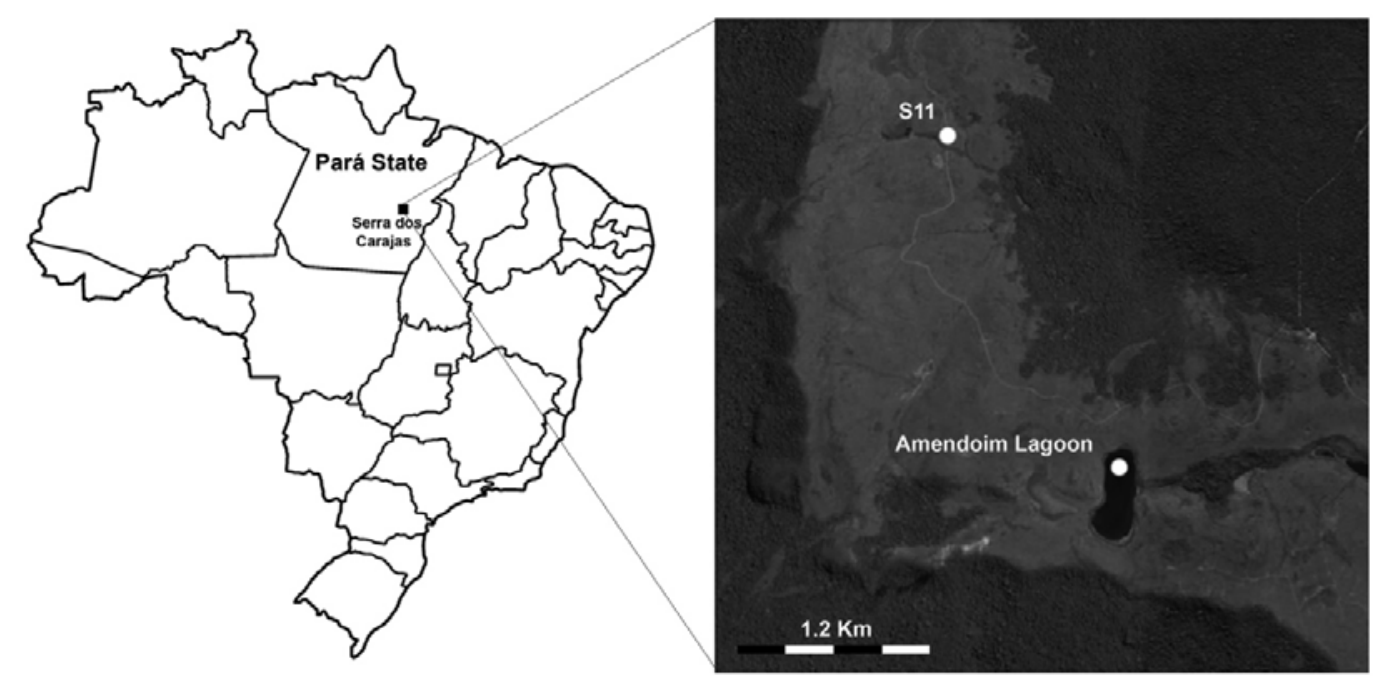

Figure 1. Iron Rocky Outcrops from Serra dos Carajás, Pará State, Brazil. I. cangae was collected in Amendoin lagoon, while I. serracarajensis was gathered in the ferruginous plateaus, flooded S11. 

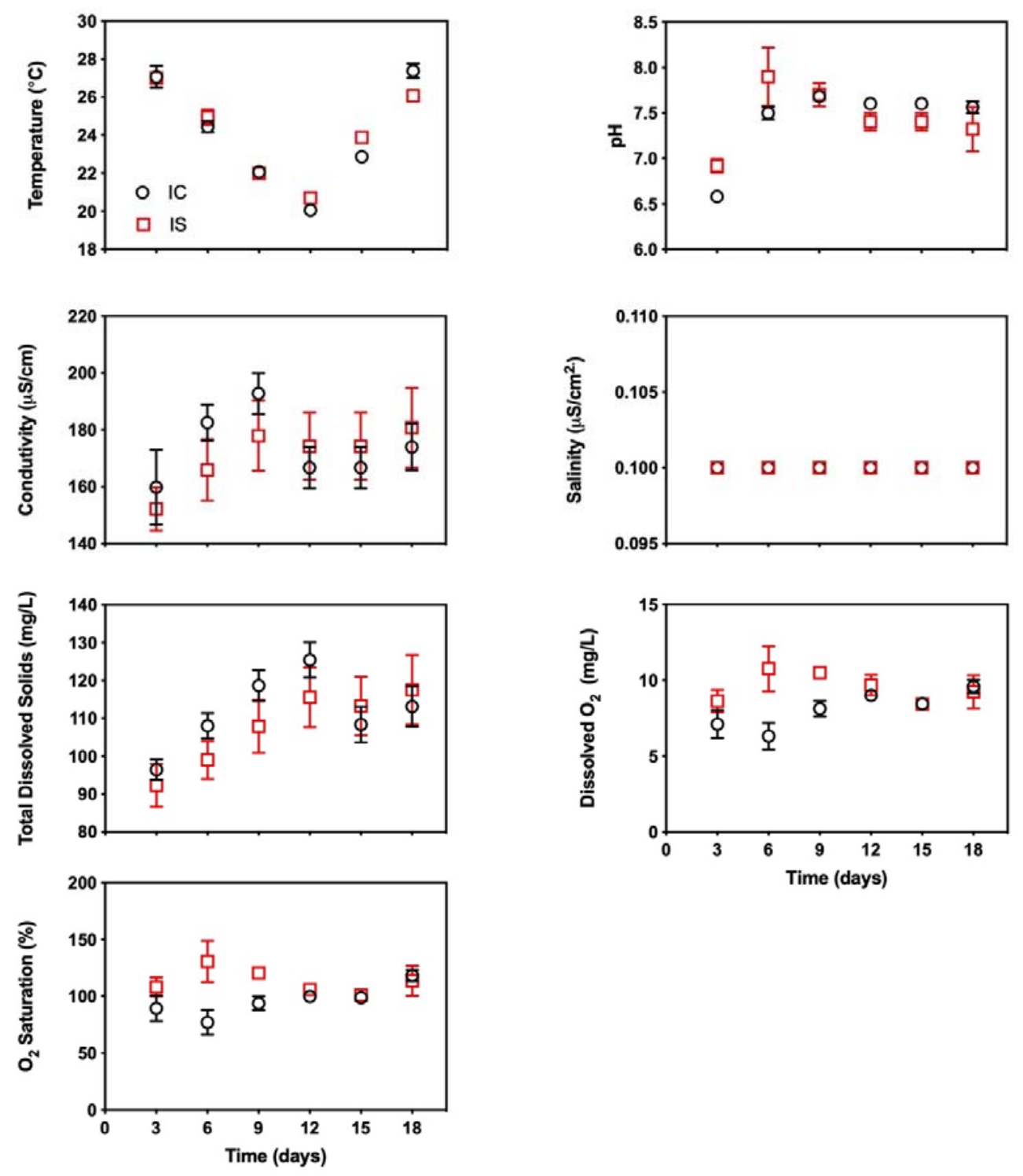

Figure 2. Physicochemical characteristics of the water. Temperature, $\mathrm{pH}$, Conductivity, Salinity, Total Dissolved Solids, Dissolved $\mathrm{O}_{2}$ and $\mathrm{O}_{2}$ Saturation. Isoetes cangae (I.C. - open black circles) and Isoetes serracarajensis (I.S. open red squares). 

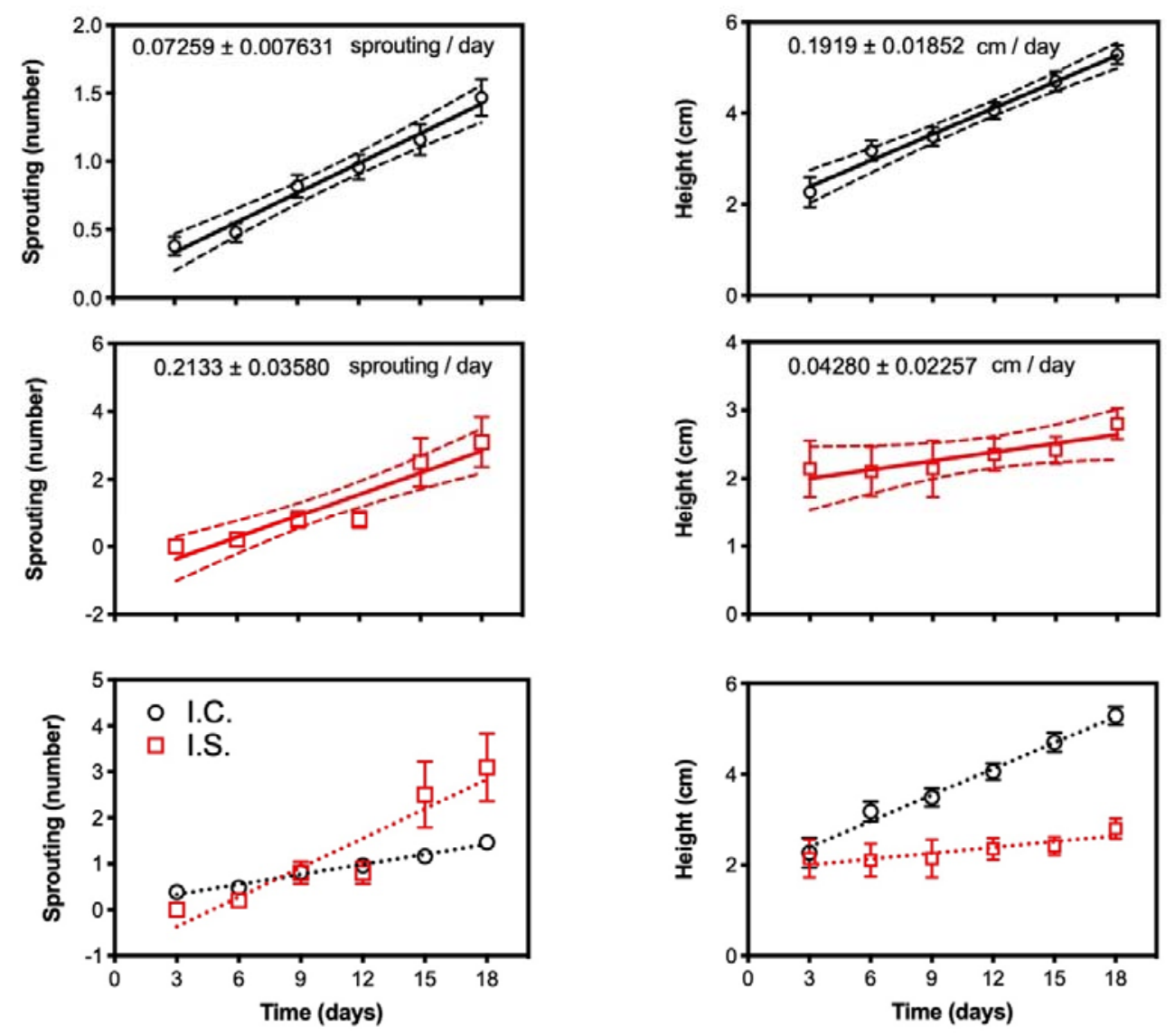

Figure 3. Sprouting rate in number of new leaves, growth in centimeters and comparative charts between species of Isoetes cangae (I.C. - open black circles) and Isoetes serracarajensis (I.S. - open red squares) in beakers. Data represent means from three independent experiments \pm confidence interval $(n=12$ in each experiment). 




Figure 4. Plasma membrane $\mathrm{H}^{+}$-ATPase activity. Values are presented as means \pm standard deviation (SD) of ten individual plants per specie; two asterisks indicate values that were determined by the t-test to be significantly different $(P<0.001)$. 




Species

Figure 5. Photosynthetic performance of the two studied Isoetes species in regard to leaf exposition to air (black circle denotes leaves above water line, and black triangle denotes leaves below water line). The effective quantum yield of photosystem II (PS II) $(\Delta F / F m)$ was accessed on the two species at two leaf positions: below and above the water line. Values are presented as means \pm standard deviation (SD) of ten individual plants per species. Asterisk denotes statistical difference between genotypes at $\mathrm{P}<0.05$. 

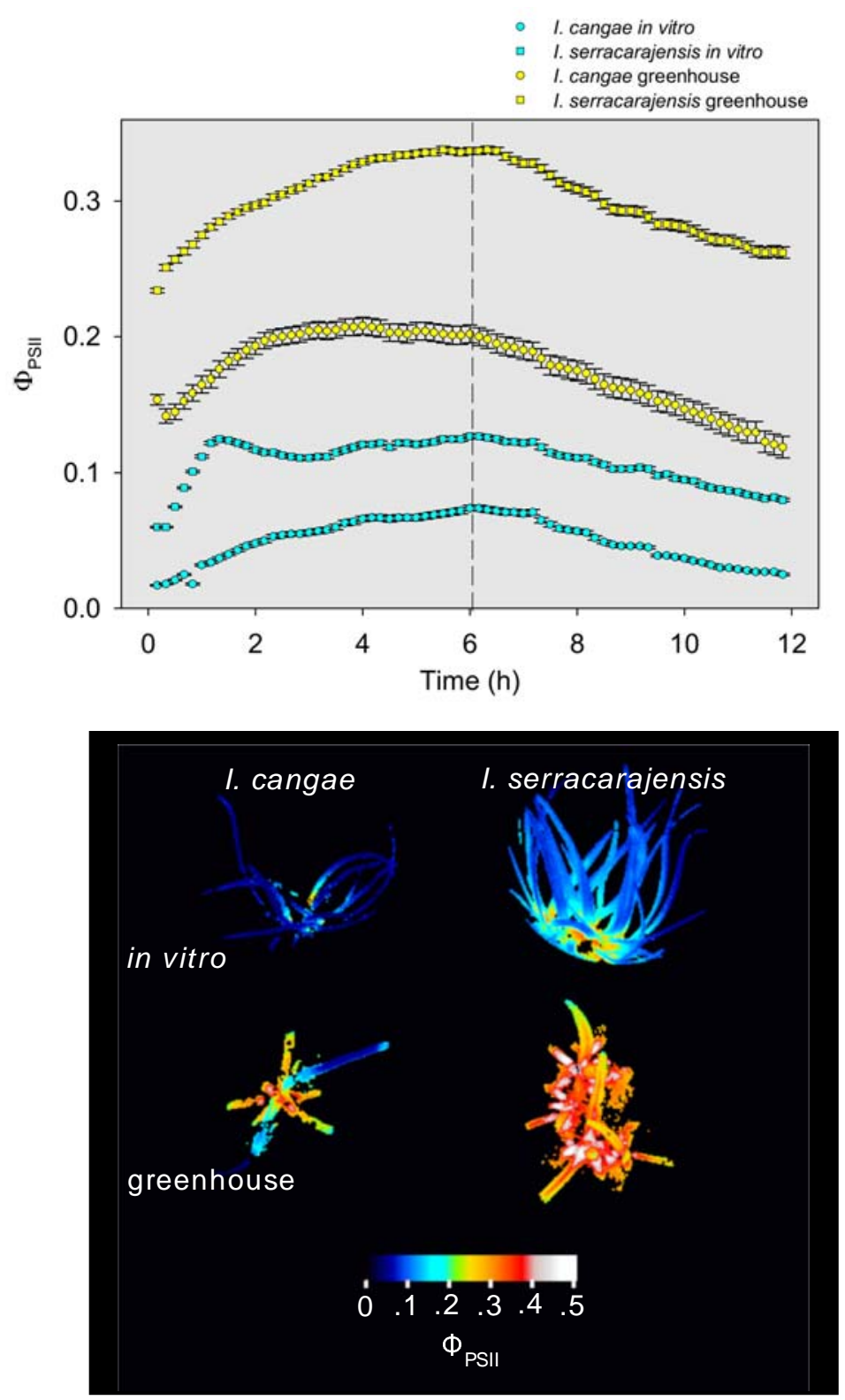

Figure 6. Diurnal course of $\Phi_{\mathrm{PSII}}$ in two $I$. cangae and $I$. serracarajensis cultivated in vitro and in greenhouse obtained by serial imaging of $\Phi_{\mathrm{PS} \|}$ every 10 minutes within 12 hours. Plots are entire plant mean of $\Phi_{\mathrm{PS} \|}$ and error bars are confidence intervals at $p<0.001$ (Student's $t$ distribution). The image bellow show example plants measured at $6^{\text {th }}$ hour. 

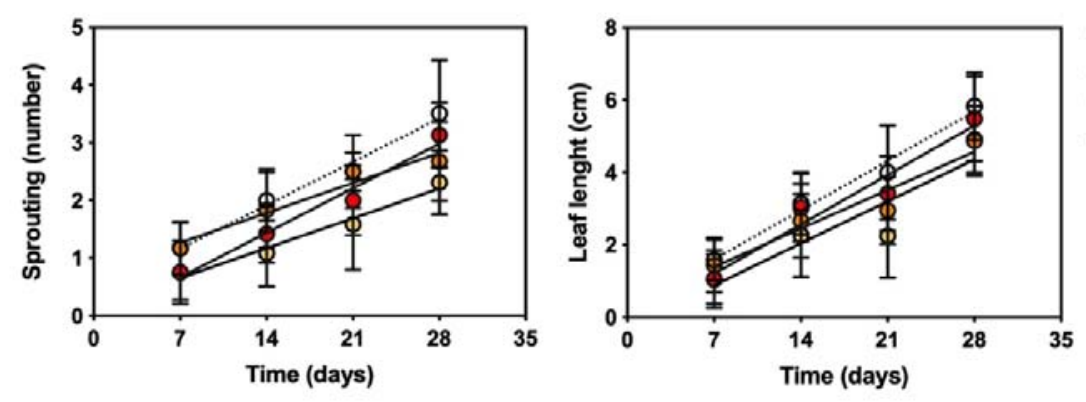

๑. $0,0 \mathrm{mg} / \mathrm{L}$ Fe EDTA

$0,0,2 \mathrm{mg} / \mathrm{L} \mathrm{Fe} \mathrm{EDTA}$

- 0 - $0,6 \mathrm{mg} / \mathrm{L}$ Fe EDTA

$\rightarrow 1.8 \mathrm{mg} / \mathrm{L}$ Fe EDTA

Figure 7. Sprouting rate and growth of $I$. cangae as a function of different concentrations of iron (FeEDTA 0.2; 0.6 e $1.8 \mathrm{mg} / \mathrm{L}$ ). Dotted lines are linear regression of control plants (FeEDTA $0.0 \mathrm{mg} / \mathrm{L}$ ). 
•๑. $0.0 \mathrm{mg} / \mathrm{L}$
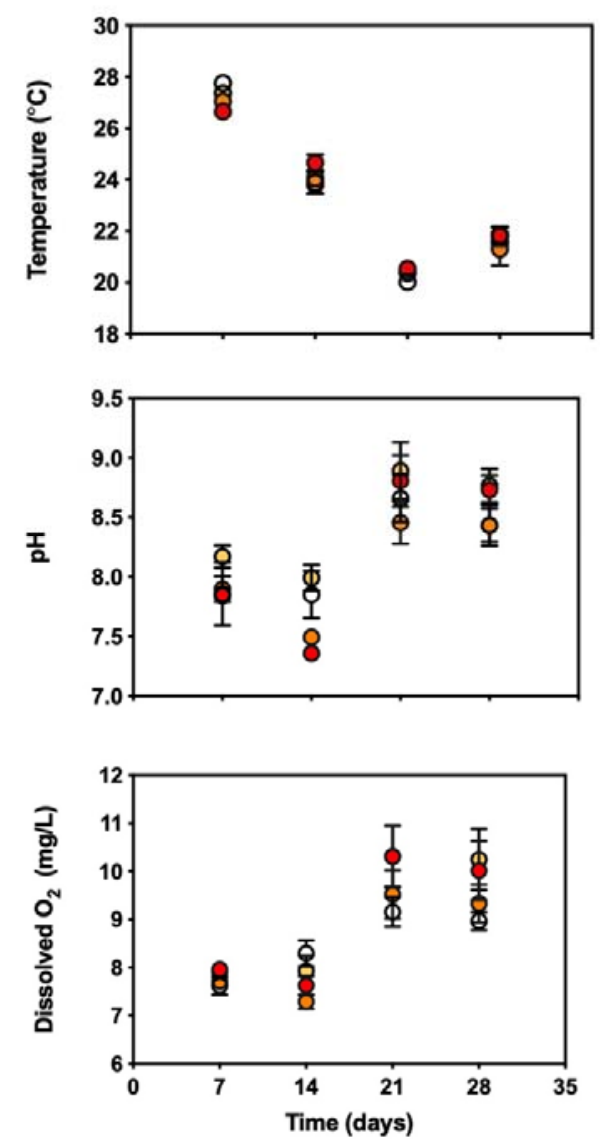

- $0.6 \mathrm{mg} / \mathrm{L} \quad-0-1.8 \mathrm{mg} / \mathrm{L}$
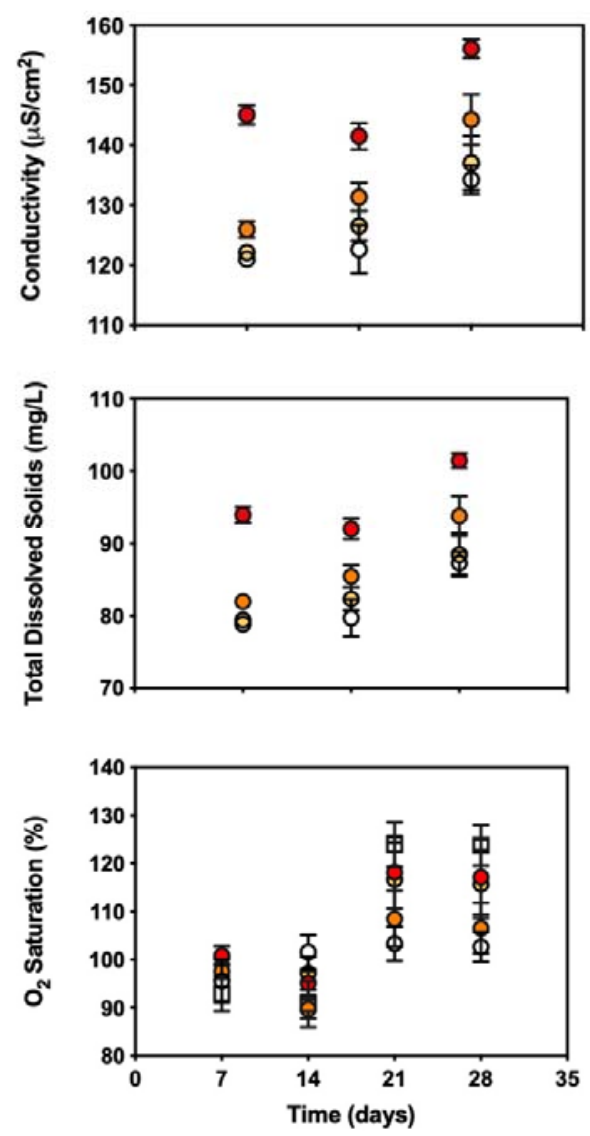

Figure 8. Physicochemical characteristics of the water in the beckers with different iron concentrations (FeEDTA 0.2; 0.6 e $1.8 \mathrm{mg} / \mathrm{L}$ ). Temperature, $\mathrm{pH}$, Conductivity, Salinity, Total Dissolved Solids, Dissolved $\mathrm{O}_{2}$ and $\mathrm{O}_{2}$ Saturation. 

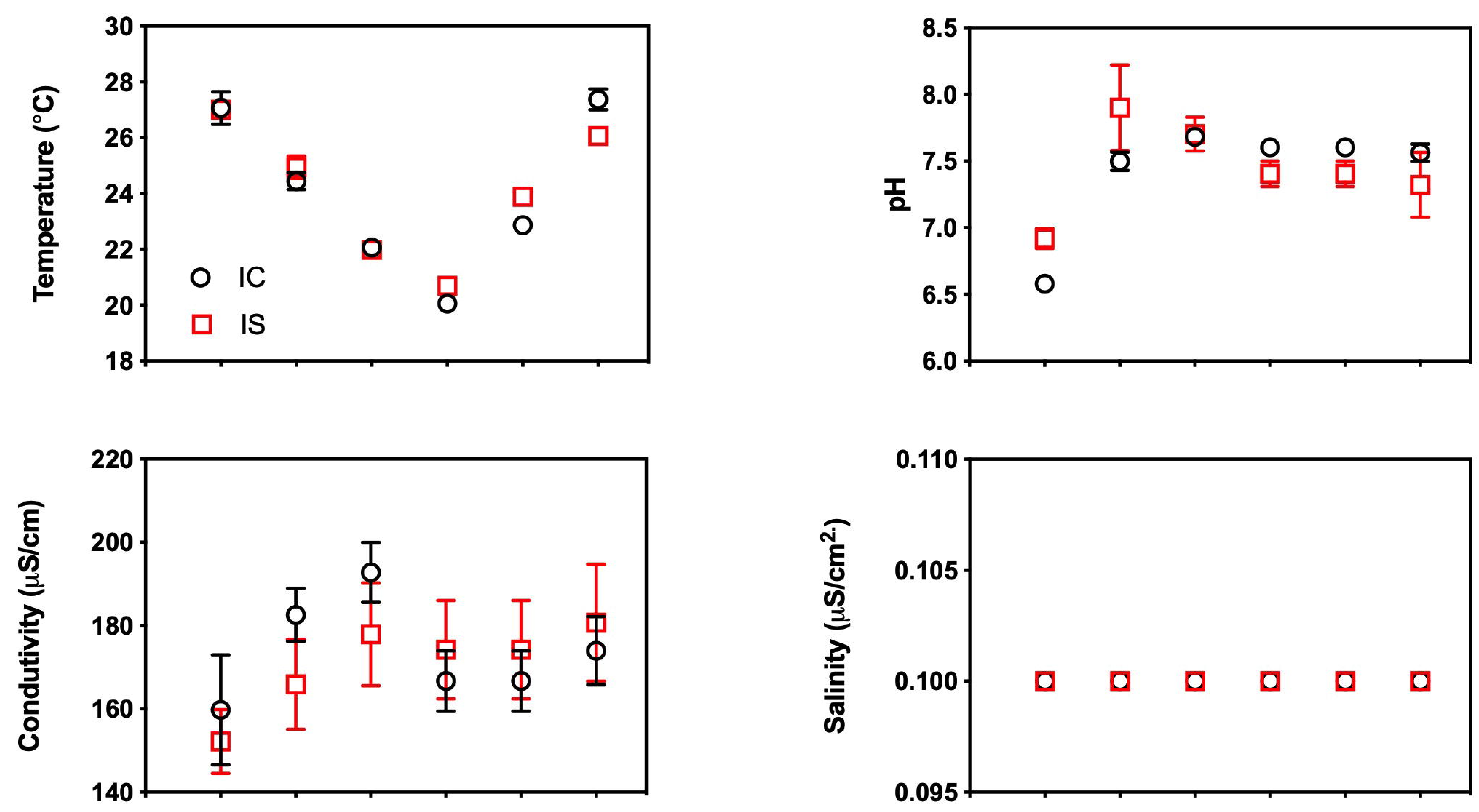

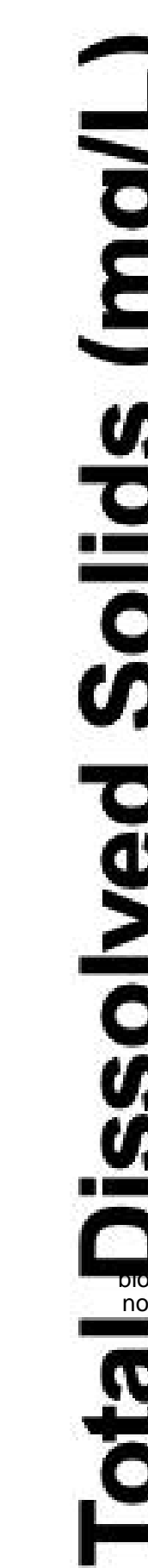
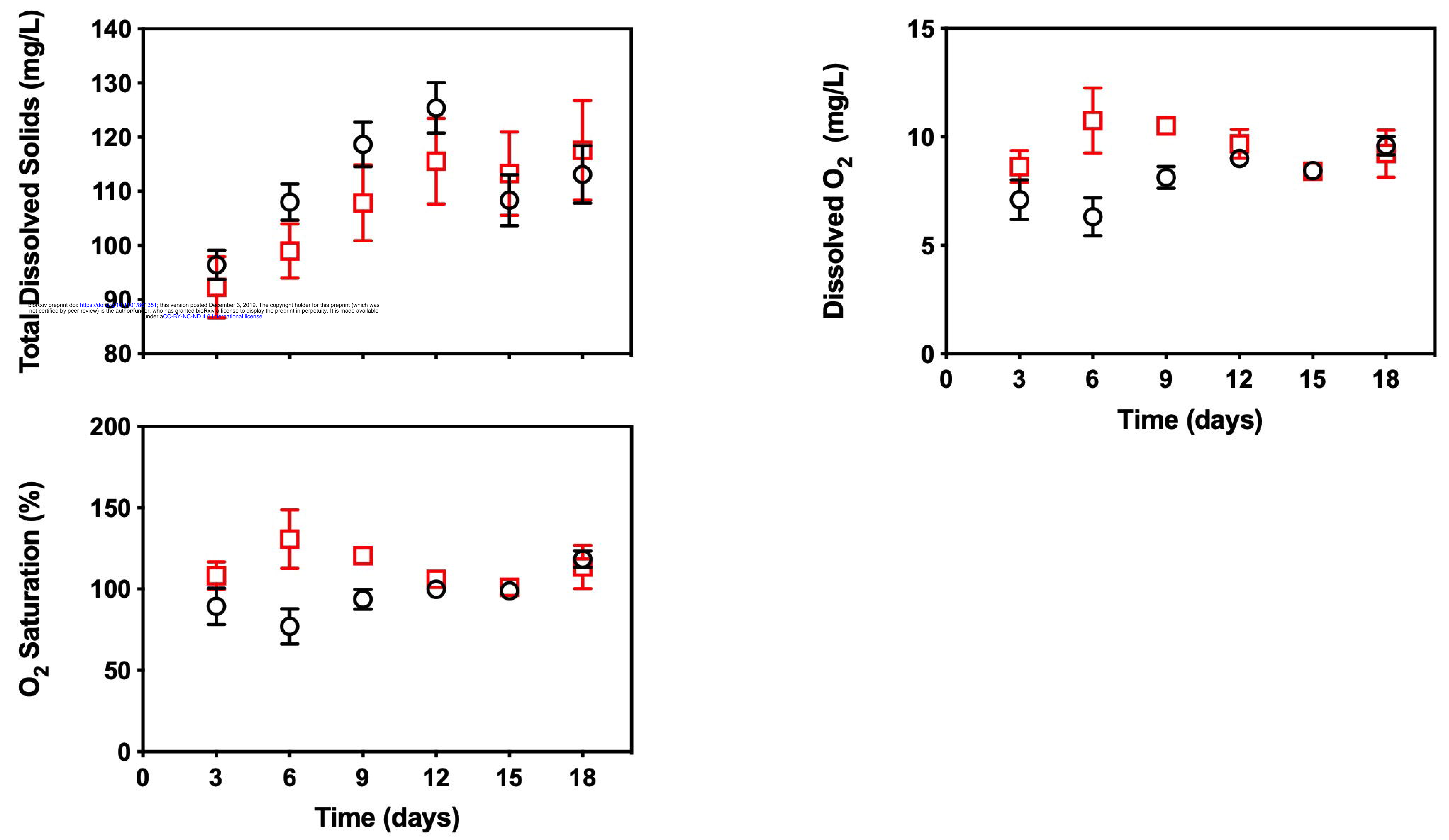

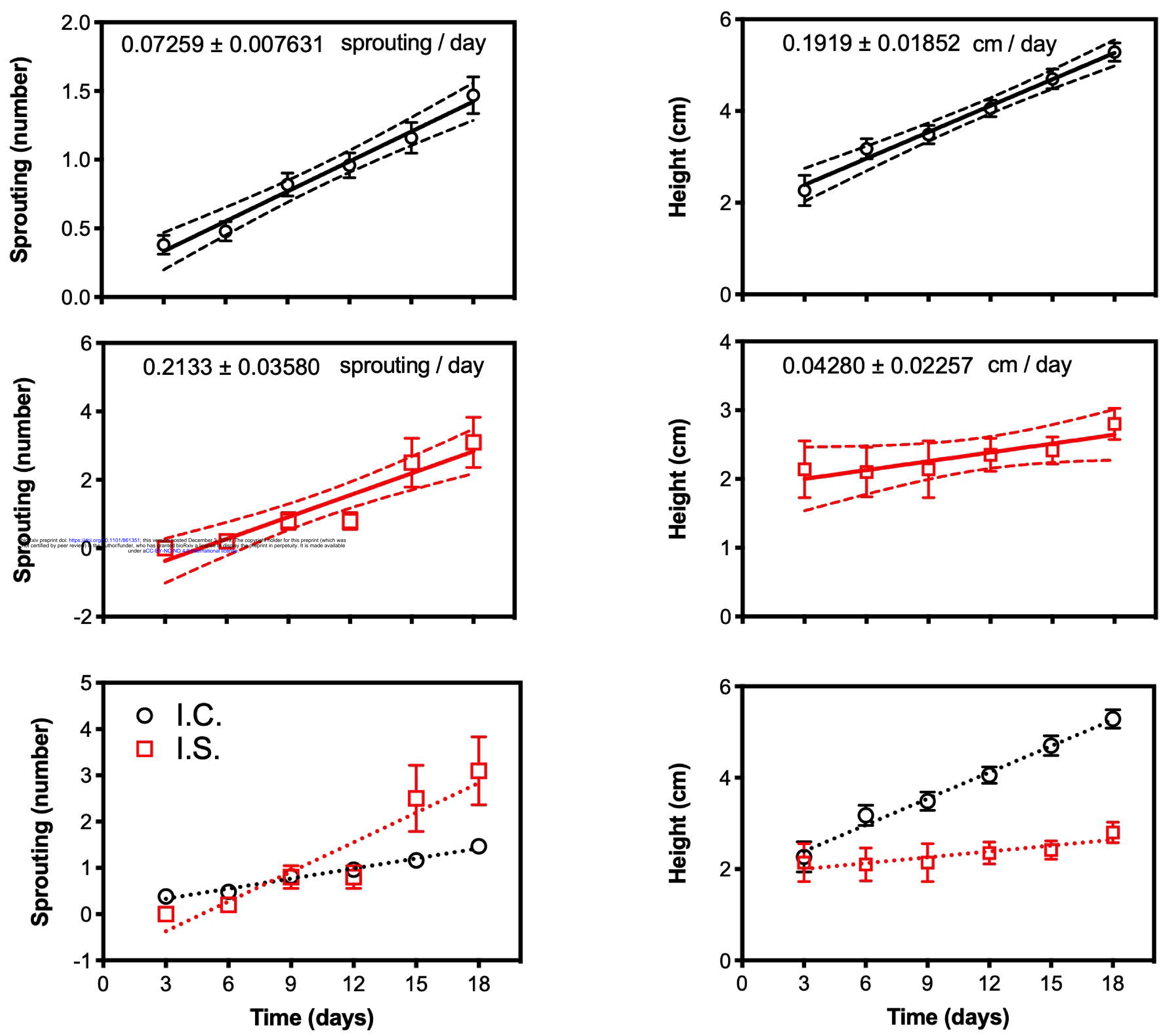


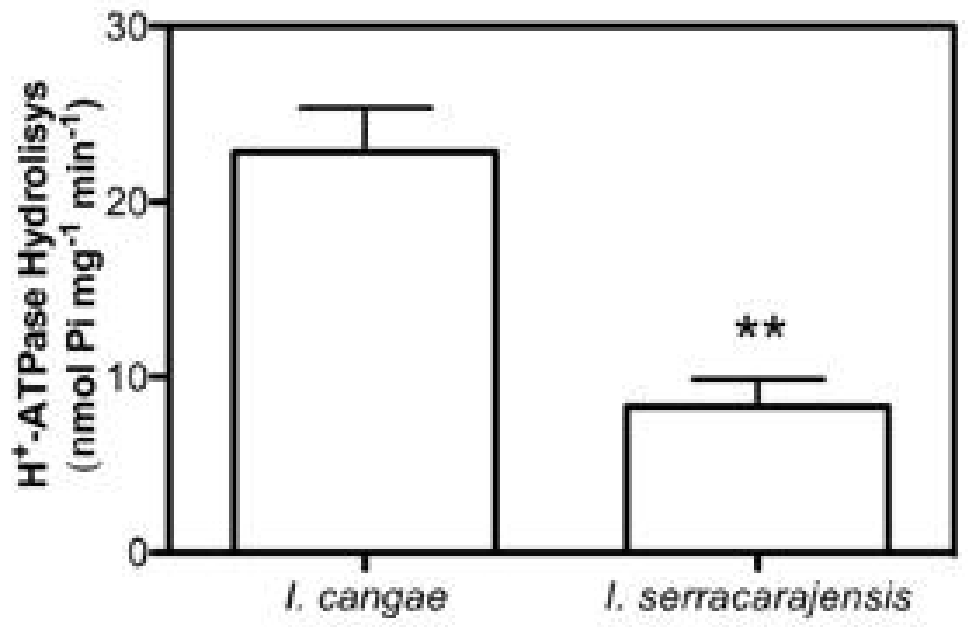




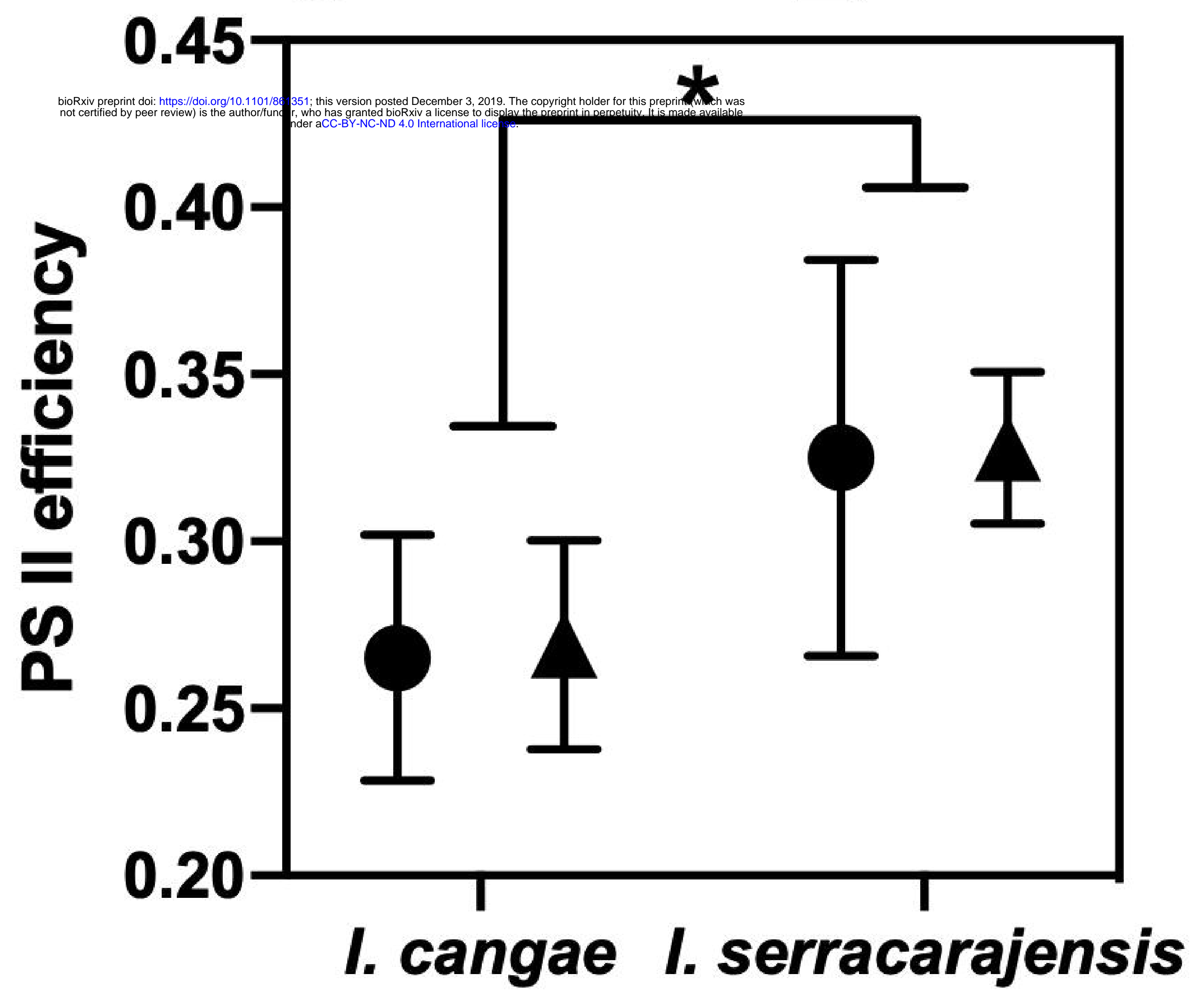

\section{Species}


- I cangse in vito

* I. asmacarajensala in vitro

- l cangse greenhouse

= I. semscarswols greerhouse

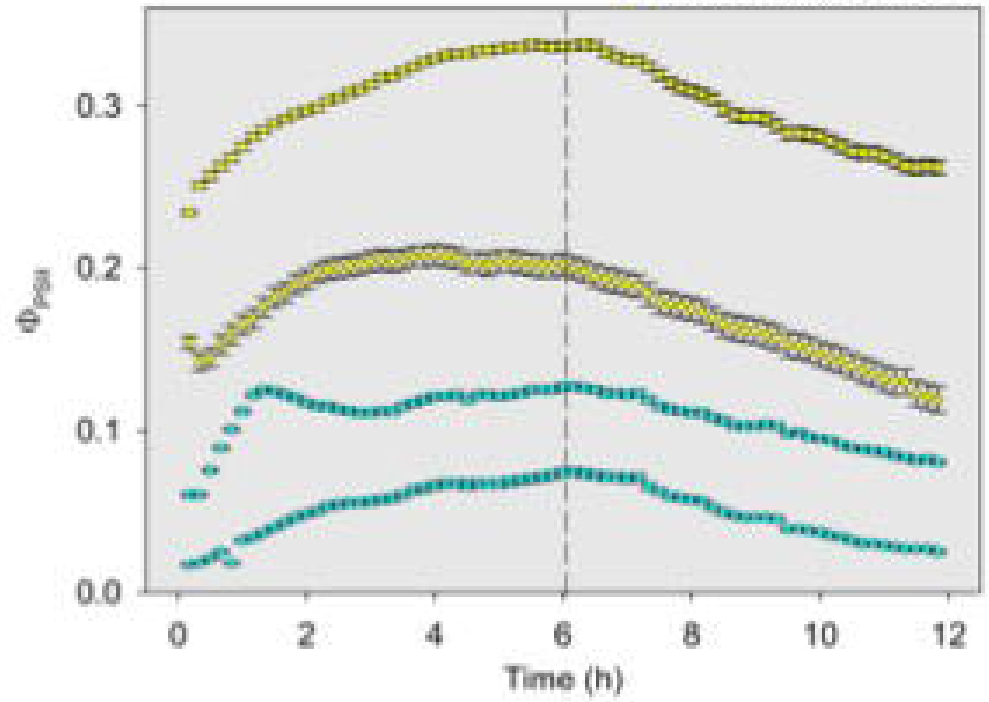

\section{I. cangae}

1. serracarajensis

\section{in vitro}

\section{i.}
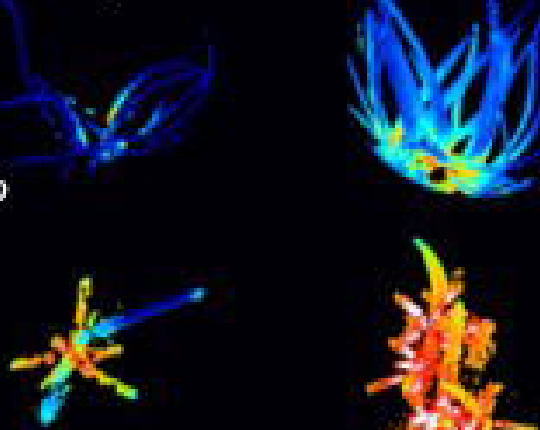

greenhouse

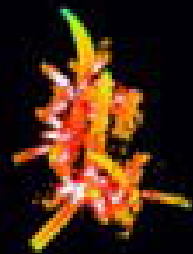

0 1.1 .2 .3 .4 .5 

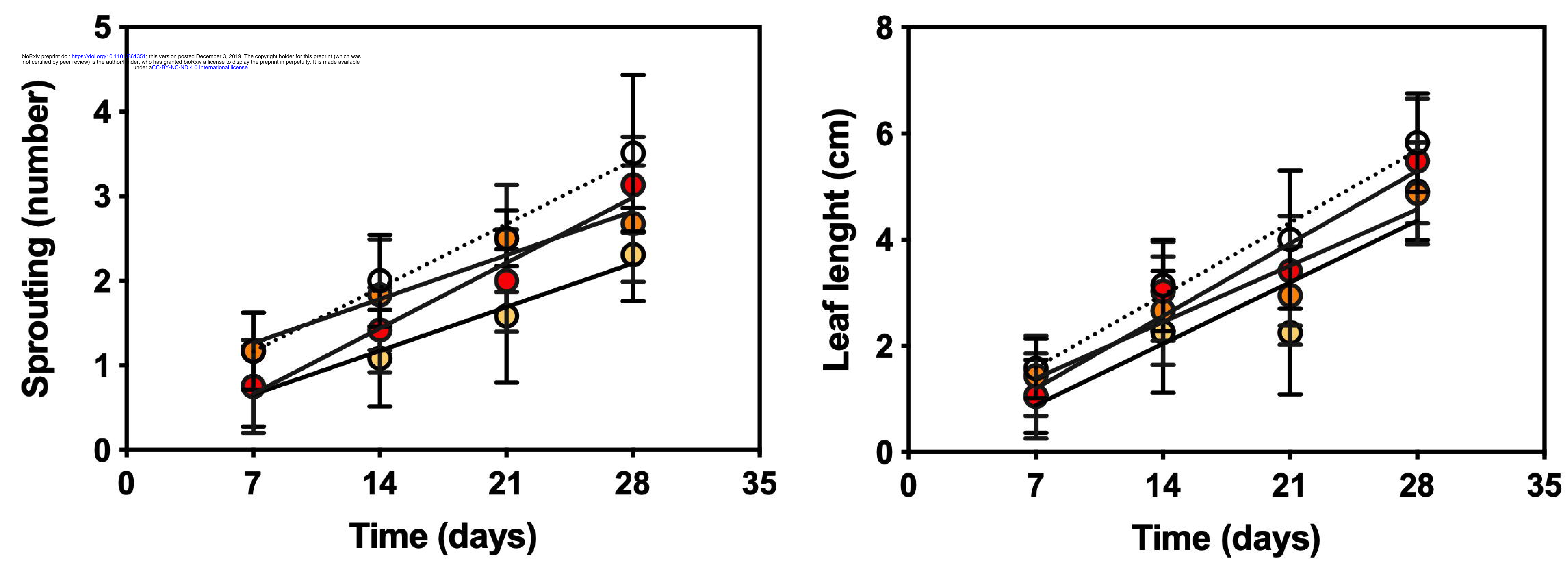

๑. $0,0 \mathrm{mg} / \mathrm{L} \mathrm{Fe}$ EDTA - $-0,2 \mathrm{mg} / \mathrm{L}$ Fe EDTA - 0 - 0,6 mg/L Fe EDTA - $-1.8 \mathrm{mg} / \mathrm{L} \mathrm{Fe}$ EDTA 
.๑. $0.0 \mathrm{mg} / \mathrm{L} \quad-0-0.2 \mathrm{mg} / \mathrm{L}$

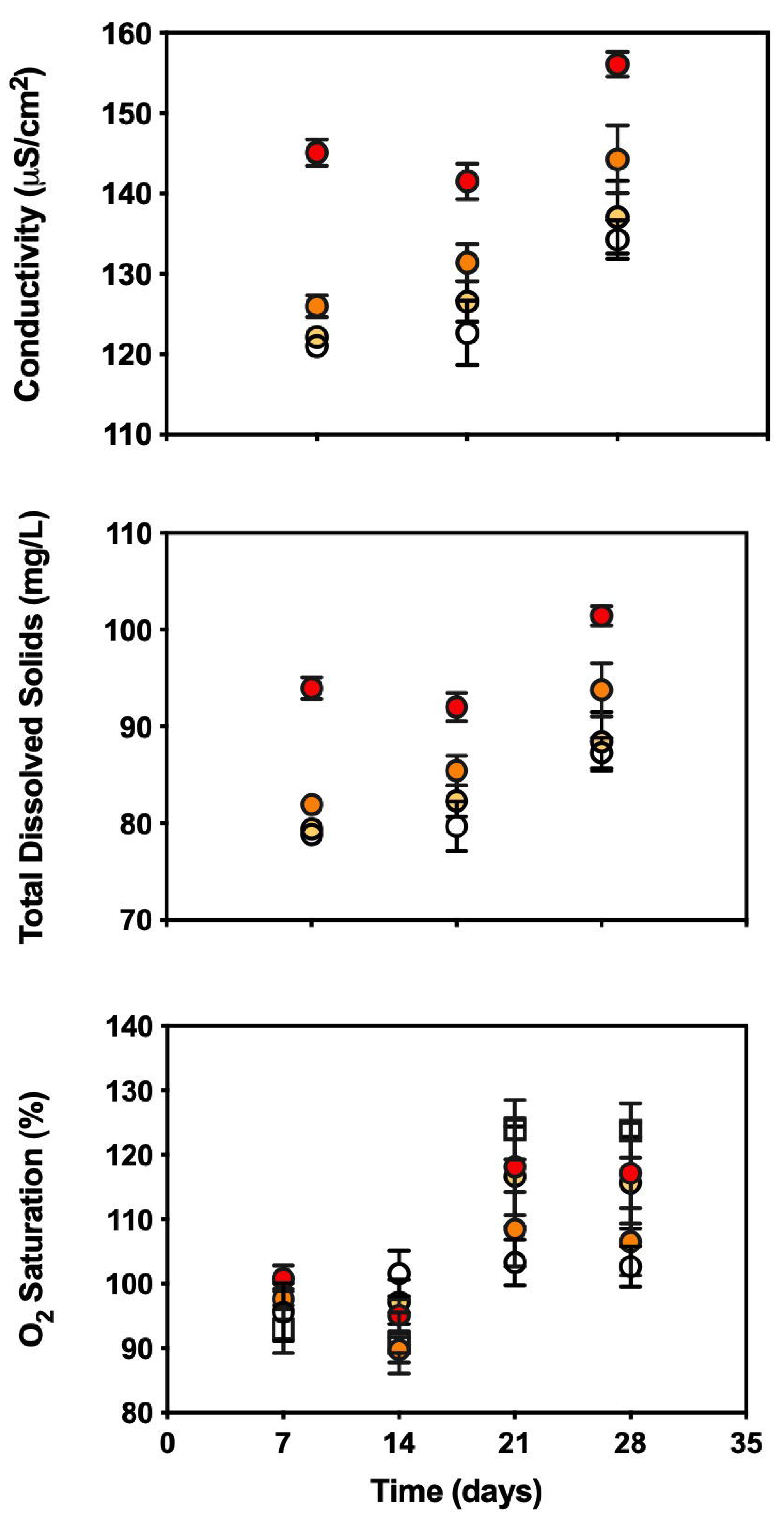